Published in final edited form as:

Drug Metab Rev. 2013 February ; 45(1): 60-72. doi:10.3109/03602532.2012.746363.

\title{
PXR antagonists and implication in drug metabolism
}

\author{
Sridhar Mani ${ }^{1}$, Wei Dou ${ }^{2}$, and Matthew R. Redinbo ${ }^{3}$ \\ ${ }^{1}$ Departments of Medicine and Genetics, Albert Einstein College of Medicine, Bronx, New York, \\ USA
}

${ }^{2}$ Shanghai Key Laboratory of Formulated Chinese Medicines and MOE Key Laboratory for Standardization of Chinese Medicines, Institute of Chinese Materia Medica, Shanghai University of Traditional Chinese Medicine, Shanghai, China

${ }^{3}$ Department of Chemistry, University of North Carolina, Chapel Hill, North Carolina, USA

\begin{abstract}
Adopted orphan nuclear receptor (NR), pregnane X receptor (PXR), plays a central role in the regulation of xeno- and endobiotic metabolism. Since the discovery of the functional role of PXR in 1998, there is evolving evidence for the role of PXR agonists in abrogating metabolic pathophysiology (e.g., cholestasis, hypercholesterolemia, and inflammation). However, more recently, it is clear that PXR is also an important mediator of adverse xeno- (e.g., enhances acetaminophen toxicity) and endobiotic (e.g., hepatic steatosis) metabolic phenotypes. Moreover, in cancer therapeutics, PXR activation can induce drug resistance, and there is growing evidence for tissue-specific enhancement of the malignant phenotype. Thus, in these instances, there may be a role for PXR antagonists. However, as opposed to the discovery efforts for PXR agonists, there are only a few antagonists described. The mode of action of these antagonists (e.g., sulforaphane) remains less clear. Our laboratory efforts have focused on this question. Since the original discovery of azoles analogs as PXR antagonists, we have preliminarily defined an important PXR antagonist pharmacophore and developed less-toxic PXR antagonists. In this review, we describe our published and unpublished findings on recent structure-function studies involving the azole chemical scaffold. Further work in the future is needed to fully define potent, more-selective PXR antagonists that may be useful in clinical application.
\end{abstract}

\section{Keywords}

Pregnane x receptor; antagonist; pharmcophore; drug metabolism; adverse drug interactions

\section{Introduction}

A fundamental tenet in drug metabolism implies that any drug (or xenobiotic) undergoes biotransformation and transport using coordinately expressed systems (i.e., enzymes and transporters). This tandem expression of enzymes and transporters is largely controlled at the level of transcription. This control is tissue restricted, specific, and attributed to ligand-

\footnotetext{
(C) 2013 Informa Healthcare USA, Inc.

Address for Correspondence: Sridhar Mani, Departments of Medicine and Genetics, Chanin 302D-1, Albert Einstein College of Medicine, 1300 Morris Park Avenue, Bronx, NY 10461, USA; Fax: 718-430-8505; sridhar.mani@ einstein.yu.edu.

Declaration of interest

Funding for work presented in this review came from the Albert Einstein Cancer Center (Albert Einstein College of Medicine, Bronx, New York, USA) as well as grants from the National Institutes of Health (CA 127231) and the Damon Runyon Foundation Clinical Investigator Award (CI15-02, and National Natural Science Foundation of China (81150040, 81273572)).
} 
regulated transcription factors. One such master regulator is pregnane $\mathrm{X}$ receptor (PXR) (Kliewer, 2003; Kliewer et al., 1998, 1999, 2002; Blumberg et al., 1998; Lehmann et al., 1998; Moore et al., 2002; Moore and Kliewer, 2000; Bertilsson et al., 1998). Ligand- and non-ligand-regulated activation of PXR controls key xenobiotic metabolic pathways that involve the coordinate expression of enzymes involved in phase I (oxidation) and II (conjugation) and transporters (elimination) (Kliewer et al., 1999, 2002; Synold et al., 2001).

\section{The nuclear receptor (NR) superfamily}

The NR superfamily is composed of transcriptional regulators that control the assembly of the basal machinery and can significantly affect target gene-expression levels. The canonical $\mathrm{NR}$ fold includes an N-terminal ligand-independent activation function 1 (AF-1) region, a zinc-module-containing, sequence-specific DNA-binding domain (DBD), a flexible hinge, and a ligand-binding domain (LBD) with a ligand-dependent activation function 2 (AF-2) surface at the far C-terminus of the protein. NRs are typically classified as steroid receptors [e.g., estrogen (ER), progesterone (PR), and androgen receptor (AR), respectively), adopted orphan receptors [e.g., liver X (LXR), farnesoid X (FXR), and peroxisome proliferatoractivator receptor (PPAR), respectively], and orphan receptors (e.g., COUP-TF, NGFI-B, and RVR). Steroid receptors have been shown to function as homodimers and adopted orphans as heterodimers with retinoid $\mathrm{X}$ receptor alpha (RXRa). NRs also typically respond to a specific set of relative-affinity ligands (e.g., estrogen, oxysterols, and bile acids for ER, LXR, and FXR, respectively). Upon ligand binding, the AF-2 region of the LBD adopts a conformation that dissociates corepressor proteins and enhances binding to transcriptional coactivators, which, in turn, facilitate the recruitment of the basal transcription machinery to upregulate gene expression (Figure 1) (Chawla et al., 2001; Gronemeyer et al., 2004; Mangelsdorf et al., 1995).

However, there are numerous examples of NRs that vary this canonical NR paradigm. For example, monomeric NRs exist (e.g., liver receptor homolog 1; LRH-1), as well as NRs that lack a DBD (e.g., short heterodimer partner; SHP) and a detectable ligand-binding cavity within its LBD (e.g., Nurr1) (Chawla et al., 2001; Gronemeyer et al., 2004; Mangelsdorf et al., 1995). As outlined below, PXR is unusual in the NR superfamily in its ability to bind to a wide array of structurally distinct ligands (Orans et al., 2005).

\section{Promiscuity in ligand binding by PXR}

PXR was originally cloned from mice and shown to respond to endogenous pregnane ligands (Kliewer et al., 1998). The human homolog was also simultaneously characterized (Blumberg et al., 1998; Lehmann et al., 1998). It has subsequently been adopted as a nuclear xenobiotic receptor and to regulate the expression of protective gene products in response to potentially toxic exogenous (i.e., xenobiotics) and endogenous chemicals (Blumberg et al., 1998; Lehmann et al., 1998; Moore et al., 2002; Moore and Kliewer, 2000). PXR functions as a heterodimer with RXRa and controls gene expression in response to ligands as small as the cholesterol-lowering compound, SR12813 (268Da), to the macrolide antibiotic, rifampicin (823Da) (Figure 2) (Orans et al., 2005). In addition, PXR responds to several potentially toxic bile acids, such as lithocholic acid. Although most NR LBDs exhibit high sequence identity between orthologs in different species (e.g., 72\% identity for ER LBDs) (Thornton, 2001), PXR LBDs from different species vary relatively widely in sequence (e.g., 50-75\% identity) and respond to distinct sets of ligands that likely reflect different xeno- and endobiotic pressures during evolution (Reschly and Krasowski, 2006).

\section{Crystal structures of the human PXR LBD}

Structural studies have revealed that the human PXR LBD exhibits an overall fold similar to most NR LBDs, but with several unique features that enhance its promiscuity in ligand 
binding. The PXR LBD contains the three-layer helical sandwich first described for RXRa, but modifies the LBD scaffold to include an extended five-stranded antiparallel $\beta$-sheet, instead of the two- to three-stranded $\beta$-sheet commonly observed (Figure 3) (Watkins et al., 2001, 2002, 2003a, 2003b; Goodwin et al., 2002). As a consequence, PXR frames a large, structurally conformable ligand-binding pocket that can accommodate both large and small ligands. The binding pocket of steroid receptors are typically 369-697 $\AA^{3}$, whereas PXR's pocket varies from 250 to $1,150 \AA^{3}$ (Watkins et al., 2001, 2002, 2003b; Benoit et al., 2004). The size of the pocket, and the mobility of side chains and untethered loops that line the pocket, facilitate structural changes that enhance promiscuity (Figure 4) (Carnahan et al., 2005). For example, key side chains, such as His-407 and Leu-209, move by up to $8 \AA$ to accommodate small and large ligands; in addition, the 198-212 region of the protein has been observed to become completely disordered when complexed to rifampicin (Figure 4) (Carnahan et al., 2005). As outlined below, these features make antagonism of the receptor difficult.

When an activating ligand (agonist) is present, the AF-2 surface of the PXR LBD is stabilized in a conformation that allows the binding of a leucine-rich motif (e.g., NR boxes) found in transcriptional coactivators, such as the steroid receptor coactivator proteins (e.g., SRC-1, -2, and -3). These relatively short motifs dock as alpha-helices into the AF-2 surface, burying key leucines and stabilized by a charge clamp around the helical dipole (Figure 5) (Orans et al., 2005). The AF-2 surface has recently been targeted successfully by NR antagonists (Moore et al., 2010).

\section{PXR and drug metabolic pathways: a case for PXR antagonists}

With regard to drug metabolism, some examples might illustrate the importance of the use of PXR antagonists. As noted from the mechanism of action of PXR, this receptor is involved in clinically important drug-drug interactions (DDIs). In the context of this review, PXR-mediated drug interactions result in a significant number of adverse drug interactions (ADIs). Indeed, ADIs account for 10-17\% of medical indications for hospital admissions for elderly patients (Beard, 1992). In some estimates, ADIs represent the fourth- to sixth-leading cause of death in the United States (Lazarou et al., 1998; Bates, 1998). Induction or inhibition of cytochrome P450s (CYPs) represents one of the most common causes of DDIs, and many of these interactions involve CYP3A4 (Guengerich, 1997).

For example, use of rifampicin, an established antituberculosis drug, can activate human PXR at concentrations used in the clinic (Biswas et al., 2009). Indeed, in situations with coexistent illnesses, PXR activation can adversely affect (i.e., inactivate) other concomitantly delivered drugs, including anti-HIV (human immunodeficiency virus) protease inhibitors, oral contraceptive, thiazolidinediones, and benzodiazepines, such as midazolam and methadone (CYP3A substrates) (Biswas et al., 2009; Niemi et al., 2003; Back and Orme, 1990; Barry et al., 1997; Dowell et al., 2004; Grub et al., 2001; Jayasagar et al., 2003; Kakuda et al., 2011; Lotsch et al., 2002; Meyer, 1976; Pea et al., 2008; Poirer et al., 2007; Rosskopf et al., 2009; Schafer-Korting, 1993; Sheen, 2007; Vethe et al., 2011). Clinical consequences of such adverse interactions are observed with cyclosporine (transplant rejection) (Ruschitzka et al., 2000), loss of drug efficacy (anti-HIV and coadministered drugs) (Curran and Ribera, 2011; Kredo et al., 2011), potential loss of efficacy of irinotecan, despite added benefit of protection from intestinal toxicity when PXR is activated (Borrelli and Izzo, 2009; Hu et al., 2007), loss of efficacy with imatinib (approved treatment for chronic myeloid leukemia) (Borrelli and Izzo, 2009), methadone withdrawal (Kharasch et al., 2005; Bending and Skacel, 1977; Fromm et al., 1997; Holmes, 1990; Kreek et al., 1976; Anonymous, 2006), and fatigue with selective serotonin reuptake inhibitors (Hu et al., 2007; Cheng et al., 2009). Another example of drug interactions leading to liver toxicity is of isoniazid and 3-methylcholanthrene, which can accelerate the 
metabolism of acetaminophen. This interaction can result in accumulation of the alkylating metabolite, $N$-acetyl- $p$-benzo-quinone imine, and result in liver damage in a PXR-dependent manner (Guo et al., 2004; Lee, 2004; Burk et al., 1990; Crippin, 1993; Chen, 2010; Pondugula and Mani, 2012; Chen et al., 2012).

Another provocative role for PXR is in the regulation of xenobiotic metabolism in cancer tissue. Indeed, recent reviews have shown that PXR activation invariably mediates xenobiotic clearance and, in keeping with this, cancer drug resistance. The putative mechanisms proposed likely involve upregulation of drug-detoxifying enzymes and transporters (Pondugula and Mani, 2012), although other mechanisms hitherto undiscovered may prevail. The topic of PXR and cancer drug resistance has been reviewed previously (Chen et al., 2012), and there is growing consensus that PXR activation may indeed be an important mechanism of cancer drug resistance. It remains unclear whether this is broadly applicable to all cancer drugs or simply a subset, and this remains a subject for further studies (Pondugula and Mani, 2012; Raynal et al., 2010; Chen and Nie, 2009; Gupta et al., 2008). In keeping with this notion, there is also growing evidence that PXR activation may accelerate tumor aggressiveness in a tissue-specific context (e.g., colon cancer), whereas PXR may also inhibit such effects (e.g., breast cancer) (Pondugula and Mani, 2012; Wang et al., 2011).

PXR activation has complex effects on cholesterol metabolism, and though its activation reduces low-density lipoprotein cholesterol (elevates or reduces high-density lipoprotein) (White et al., 2010; de Haan et al., 2009; Masson et al., 2005; Cheng et al., 2012a; di Masi et al., 2009; Hernandez et al., 2009; Moreau et al., 2009; Moya et al., 2010; Zhou et al., 2009), there is also an increase in triglyceride formation (Sui et al., 2011; Hoekstra et al., 2009; Zhou et al., 2008; He et al., 2011; Jonker et al., 2012). Indeed, PXR activation is known to induce hepatic steatosis and thus has been implicated in the pathogenesis of nonalcoholic steatohepatitis. In select situations (e.g., persons with metabolic syndromes on high-fat diets), PXR antagonism, especially in the context of polypharmacy, might mitigate fat accumulation and deposition in the liver.

\section{PXR agonists}

The characteristics of PXR agonists have been reviewed previously, and readers are referred to several excellent reviews and reports (Jonker et al., 2012; Kojima et al., 2011; Yu et al., 2011; Cheng et al., 2010; Lau et al., 2010; Novotna et al., 2010; Shukla et al., 2011; Zhang et al., 2010; Dou et al., 2012; Sugatani et al., 2004; Cheng et al., 2012b). These agonists could serve as potential drugs for certain human conditions (e.g., inflammation) (Lau et al., 2010; Gollamudi et al., 2008).

\section{PXR antagonists}

Adverse PXR-dependent drug interactions may well be avoided if suitable PXR antagonists were widely available. Indeed, the ideal small molecule would have good drug-like properties, but be devoid of nonspecific cell-target effects and ability to induce cytotoxicity. Alternatively, the pharmaceutical industry has taken the strategy to develop compounds that lack PXR activity. Our laboratory has focused on developing nontoxic small-molecule antagonists targeting ligand-activated PXR. The rationale for such an approach stems from the observation that inappropriate activation of PXR by drugs contributes toward unwanted adverse events (Beard, 1992; Lee, 2004; Pondugula and Mani, 2012; Zhang et al., 2010). In the context of cancer therapy, in addition to DDIs, there might be an added advantage in reversing PXR-mediated cancer drug resistance and tumor growth (Chen et al., 2012; Svecova et al., 2008). 
The first PXR antagonist reported to function in this capacity was ET-743 (Synold et al., 2001), which was subsequently followed by reports that included compounds such as polychlorinated biphenyls, camptothecin, ketoconazole, fluconazole, enilconazole (Huang et al., 2007; Ekins et al., 2007, 2008; Dvorak, 2011; Wang et al., 2007; Duret et al., 2006; Takeshita et al., 2002; Mani et al., 2005; Zhou et al., 2007; Chen et al., 2010), sulforaphane (Zhou et al., 2007), A792611 (HIV protease inhibitor) (Healan-Greenberg et al., 2008), metformin (Krausova et al., 2011), sesamin (naturally occurring lignan) (Lim et al., 2012), fucoxanthin (Liu et al., 2012), and coumestrol (Wang et al., 2008). Notably, because these are diverse chemical entities, it is quite clear that many of the compounds bind other targets at concentrations well below the range that affects PXR (e.g., ketoconazole) (Ekins et al., 2007). Indeed, this is borne out by the fact that concentrations of ketoconazole used for therapeutic purposes are clearly not high enough or sustained $(>10 \mu \mathrm{M}$ for at least $48-72$ hours) to antagonize PXR activation in vivo (Fuchs et al., 2012), and thus would lead to the erroneous conclusion that ketoconazole would not inhibit PXR activation in vivo. The doses required to inhibit PXR in vivo would likely to yield unacceptable toxicity, and these issues have led toward a search for safer and more high-potency ketoconazole analogs that antagonize PXR (Dvorak, 2011; Das et al., 2008). If PXR activation can alter drug pharmacokinetics in humans (Baciewicz et al., 2008), then it stands to reason (or is plausible) that its inactivation would have the opposite result, depending on the degree of mixed effects of the antagonist (e.g., concomitant inhibition of target enzymes). However, in this context, there is a completed study at the University of Washington (Seattle, Washington, USA) that will analyze the effects of sulforaphane on PXR-mediated DDIs in humans (http://clinicaltrials.gov/ct2/show/NCT00621309). The results of this study have been recently reported and do not support the notion that sulphoraphane antagonizes PXR activation in humans; however, the concentrations needed to sustain this effect was also not achieved in vivo. Furthermore, there was an absence of effect in a humanized PXR mouse model which further complicates the true effects of sulphoraphane in humans (Poulton et al., 2012). Contrary to these observations, our ketoconazole analog, K2 (illustrated in Figure 12) has potent in vivo effects in a humanized PXR mouse model (Wang et al., 2011).

The Redinbo laboratory has determined the 2.8 - $\AA$ resolution crystal structure of the PXR LBD in complex with T0901317 (T1317), an efficient agonist of both PXR and the related former orphan receptor, LXR (Xue et al., 2007). In spite of differences in the size and shape of the receptor's ligand-binding pockets, key interactions with T1317 are conserved between human PXR and human LXR. Because T1317 exhibits high affinity for the PXR LBD $\left(K_{\mathrm{d}}=\right.$ $11 \mathrm{nM}$ ), they strived to design a PXR antagonist using the T1317 scaffold. Their aim was to generate an antagonist that functioned like the anticancer drug, tamoxifen, which disrupts the function of the ER, a related NR, by displacing the a AF helix in the ER LBD. Based on the PXR-T1317 structure, several analogs of T1317 were generated. However, compounds with long extensions designed to displace aAF position were still accommodated within the PXR ligand-binding pocket and functioned as agonists (Figure 6) (Xue et al., 2007). This is likely the result of the highly flexible and promiscuous nature of the PXR LBD, which can change its shape to allow larger ligands to bind. Thus, we chose to focus on developing antagonists that disrupt PXR function by targeting surface sites distinct from the ligandbinding pocket, as outlined below.

In 2002, the antifungal compound, ketoconazole, was reported to be an antagonist of PXR (Takeshita et al., 2002). However, the mechanism of antagonism was unknown. In 2006, we showed, using a series of in vitro, cell-based, and in vivo experiments, that ketoconazole disrupted both coactivator and -repressor binding from the surface of several members of the orphan class of NRs, including PXR, CAR, FXR, LXR, and VDR (Huang et al., 2007). For PXR, this effect was found to be dependent on the presence of an established agonist, which indicated that the AF-2 surface must be stabilized before antagonism by ketoconazole 
(Figure 7) (Huang et al., 2007). We further demonstrated, using wild-type (WT) and PXR knockout mice, that PXR serves as an important determinant of paclitaxel metabolism (Mani et al., 2005). These data indicate that the activity of PXR is an important determinant of drug metabolism, which can be regulated, both in vitro and in vivo, by targeting small molecules to the AF-2 surface of the receptor.

We hypothesized that ketoconazole affects PXR transcriptional regulation by binding at the AF-2 surface, rather than in the ligand-binding pocket (Ekins et al., 2007; Dvorak, 2011; Wang et al., 2007; Duret et al., 2006; Baciewicz et al., 2008). To test this hypothesis, several single and double mutations were generated in the AF-2 region of PXR (Duret et al., 2006). Residues were replaced with corresponding amino acids from a steroid receptor (e.g., ERa) that is not antagonized by ketoconazole (Table 1). In each case, the single mutants lead to a loss of PXR activity, apparently by introducing structural distortions in the AF-2 surface of the receptor (Duret et al., 2006).

A280W appears to generate a clash with L428 of a AF, which would shift the position of this terminal alpha-helix and prevent coactivator binding. The replacement of P268 with the nonproline residue $\mathrm{H}$ may similarly disrupt the AF-2 surface by reducing the rigidity of the loop between $a 3^{\prime}$ and $a 4$, thus altering the position of a 4 . T248E appears to introduce a clash with T422, which would likely shift aAF (Figure 8) and lead to a loss in coactivator binding. Finally, replacement of K277 with Q would eliminate the capping of the electronegative helix dipole of aAF by the lysine, which may be critical to the proper positioning of aAF (Figure 8). The corresponding helix in the steroid receptor is one to two turns longer and thus cannot be capped by the equivalent side chain.

Significantly, however, the double-mutant T248E/K277Q form of PXR is active, but is not susceptible to antagonism by ketoconazole (Wang et al., 2007). The recovery of receptor activity is likely the result of a synergistic combination of effects: T248E shifts the aAF up and perhaps stabilizes the electropositive $\mathrm{N}$-terminal helix dipole (as shown in Figure 8), but the shorter K277Q residue can accommodate the shift in aAF position to create an AF-2 surface capable of coactivator binding (although not to WT levels; see Wang et al., 2007). Structural considerations also suggest that the elimination of K277 may be responsible for the loss of ketoconazole antagonism. Note that this residue is located close to the side chain of H697 in the NR box 2 of human SRC-1 (Figure 9). Ketoconazole contains an imidazole ring that may mimic this histidine side chain and compete for coactivator binding. This observation may explain why the antagonism of PXR is agonist dependent: The ordering of the AF-2 surface and, critically, K277 enhanced by ligand binding is necessary for ketoconazole binding. A lysine is conserved in this position in all the NRs susceptible to ketoconazole antagonism (PXR, CAR, FXR, and LXR), but is replaced by a nonlysine in NRs that do not respond to this compound (e.g., Q in ERa). Further, constitutively active pocket-filling mutants of PXR (Figure 10) are still susceptible to antagonism by ketoconazole. Taken together, these data suggest that the AF-2 surface is a likely binding site for ketoconazole, and preliminary evidence suggested that PXR amino acids T248 and K277 were important ketoconazole-interaction residues that mediated antagonism.

These studies have shown us that it is feasible to use genetic mutational assays to evaluate PXR residues that might explain how ketoconazole binds to and antagonizes PXR activation. However, to get a fuller appreciation of this antagonist pharmacophore, we embarked on developing a high-throughput novel yeast genetic system to study PXR antagonism. Combinatorial mutants constructed individually for study in mammalian systems would be prohibitively time-consuming. Thus, in the yeast system, we developed a two-hybrid assay to study the ketoconazole-mediated disruption of PXR/SRC-1 interaction. Yeast two-hybrid assay is a genetic system that will allow the detection of protein-protein 
interactions and is amenable for large-scale screening of mutants of desired phenotype by using either colorimetric screening assays or specific selection schemes. Our design for isolating ketoconazole mutants of PXR was as follows. We first demonstrated that ketoconazole inhibits the interaction of LexA/DB/PXR and GAL4/AD/SRC-1 by using colorimetric $\mathrm{X}$-gal assay using lac $Z$ as the reporter in the yeast two-hybrid system. In this case, the positive interaction between two proteins in the presence of a ligand, such as rifampicin, should yield blue colonies, and disruption of this interaction resulting from the presence of ketoconazole in the assay system would yield white colonies. We then screened a random library of LexA/DB/PXR mutants against GAL4/AD/SRC-1 to isolate colonies that would remain blue in the presence of ketoconazole by virtue of the mutation in PXR that renders the protein insensitive to the inhibitory action of ketoconazole. Because ketoconazole is an antifungal drug, we have isolated a mutant yeast two-hybrid reporter strain resistant to the action of ketoconazole. This occurs by virtue of a genetic loss of intracellular targets for ketoconazole (ERG3/ERG11) and not the result of permeability and export mutations. This work is ongoing; however, we have discovered several residues that indeed validate the aAF surface as one important site for ketoconazole binding and antagonism. For example, a recurring mutation screened that was deemed to be insensitive to ketoconazole antagonism was Q272H. Indeed, this residue was predicted, in a docking pharmacophore model of PXR antagonists, to be a possible interaction residue (Figure 11).

A complementary approach has also yielded useful information. We examined chemical scaffolds that might well antagonize PXR and for which there might be a basis of allosteric effects on the PXR receptor. We found three chemical scaffolds that might provide further light on the antagonist pharmacophore. In the first scaffold we studied, ketoconazole analogs, we identified the functional groups on the azole scaffold essential for activity against PXR. As outlined in Figure 12, we have found that the two aromatic rings on ketoconazole (orange and magenta) are essential, as well as the five-membered ring joining them. For example, compounds K11-K15 lack one of these essential groups and exhibit no effect on PXR-mediated transcriptional activity in transient transfection experiments.

Similarly, it was found that a polar group attached to one of the aromatic rings (orange in Figure 12) may be helpful for antagonism, but is not essential (e.g., compound K3). Finally, these studies showed that the azole ring on ketoconazole is dispensable for antagonism, as highlighted in the activity of compounds K1-2 and K4-10. Taken together, these results establish an initial structure-activity relationship (SAR) that will facilitate the design of novel compounds with improved half-maximal inhibitory concentration $\left(\mathrm{IC}_{50}\right)$ values for PXR antagonism. Indeed, compound K2 has been tested further and is far less toxic than its parent drug, ketoconazole (Das et al., 2008). Additionally, K2 was more specific as a PXR antagonist, when compared to ketoconazole (Venkatesh et al., 2011). We used molecular modeling methods with Sean Ekins (www.collaborations.com/CHEMISTRY.HTM), a key collaborator on this project, to identify compounds with structural features similar to the functional groups in ketoconazole required for antagonism. A range of potential antagonists was then screened in transient transfection studies to determine their $\mathrm{IC}_{50}$ values for inhibiting PXR-mediated transcription. A promising lead from this work was SPB3255, which exhibited an 850-nM IC 50 value against PXR (Figure 13). In examining several analogs of this compound, we found that the following structural features were important for antagonist activity: Two adjacent aromatic rings along with a second aromatic group connected by a two-atom linker region (Figure 13). These results establish a second antagonist scaffold to be used to develop novel, improved PXR-disrupting lead compounds (Dvorak, 2011; Wang et al., 2007). The last PXR antagonist scaffold we discovered was identified by high-throughput screening in collaboration with scientists at GlaxoSmithKline (Wang et al., 2008), where PXR was first characterized as the human nuclear xenobiotic receptor. The phytoestrogen, coumestrol, was shown to antagonize PXR's upregulation target genes in transient transfection assays, with an $\mathrm{IC}_{50}$ value of $11 \mu \mathrm{M}$, and to disrupt the 
binding of transcriptional coregulator binding to the AF-2 surface of the receptor (Figure 14) (Wang et al., 2008). We also showed that hydrogen bond donors were required for coumestrol antagonism, because analogs without a hydroxyl group at the compound's termini were not active (Wang et al., 2008). These data advance our understanding of the SAR required for PXR antagonism. Preliminary evidence suggests that there is a requirement for $\mathrm{H}$-bond acceptors, a hydrophobe and ring aromatic. Antagonists require a balance between hydrophobic and hydrogen bonding features (Dvorak, 2011). Although we did find that compound K2 was a more-specific PXR antagonist (in comparison with ketoconazole) (Venkatesh et al., 2011), it remains unclear whether the other ketoconazole analogs or the SBP compounds exert unique effects on PXR, because these compounds have not been thoroughly assessed by in vitro assays.

Another report has shed some light on the feasibility of discovering PXR antagonists with greater potency and specificity against PXR [personal communication, Wenwei Lin, Ph.D., and Taosheng Chen, Ph.D., St. Judes (SJ) Children's Medical Center, Memphis, Tennessee, USA]. Select compounds synthesized at SJ ( $n=21$ SJ-numbered compounds) had minimal antagonist activity against eight NRs (GR, VDR, RXRa, RXR $\beta$, FXR, PPAR $\gamma, \mathrm{LXRa}$, and LXR $\beta$ ) (i.e., inhibition activity below $20 \%$ at $40 \mu \mathrm{M}$ ) using a cell (HEK293T)-based PXRtransactivation reporter system. However, these compounds were fairly potent PXR antagonists (50\% inhibitory activity in the micromolar to submicromolar range). Further analysis of the mode of action of these compounds on PXR would enhance our understanding of how PXR activity is antagonized.

\section{Conclusions}

It is now clear that the discovery of PXR-specific antagonists is feasible; however, determining the most active pharmacophore to achieve this still remains elusive. Some of the cumbersome techniques might become simpler as we move toward isolating full-length PXR and obtain structural information regarding PXR in context with RXR, coactivators, and DNA. However, thus far, we have been successful in developing nontoxic azole analogs that may be used to antagonize PXR activation in vivo. Further, using high-throughput analysis of PXR mutants in a yeast two-hybrid system, we have also identified one important site on aAF that could serve as an allosteric site that modulates PXR activation. This discovery has clinical ramifications, but, more important, provide the basis for accelerated discovery of PXR antagonists.

Protein-protein interaction pharmacophores are shallow and do not possess the most favorable features that would fit inhibitors and antagonists (Pagliaro et al., 2004; Buzon et al., 2012; Choi et al., 2010, 2011). However, recently, it has been shown that for NRs, such sites are druggable (Biswas et al., 2009; Dong et al., 2010). Indeed, conserved alternate-site allosteric pharmacophores (e.g., BF3) have clearly shown that specific surfaces may be exploited (Biswas et al., 2009; Dong et al., 2010). Recently, it has been shown that fairly high-specificity inhibitors to select protein-interaction sites on PPAR $\gamma$ (i.e., cdk5-interaction domain) can be developed (Sugatani et al., 2012; Biswas et al., 2011). Indeed, the discovery of similar post-translational modifications on PXR might well allow for similar strategies for the discovery of novel xenobiotic ligands and antagonists (Biswas et al., 2011; Staudinger et al., 2011; Hu et al., 2010).

Finally, the implications for use of PXR antagonists in PXR-mediated drug metabolism are clear. Several conditions, namely, adverse DDIs that lead to clinical consequences, such as enhanced drug toxicity or reduced drug efficacy, can be controlled with the use of nontoxic, but potent, PXR-specific antagonists. Future development of these antagonists is warranted. 


\section{Acknowledgments}

The authors thank Drs. Matthew Redinbo (University of North Carolina, Chapel Hill, North Carolina, USA), Sean Ekins, Sandhya Kortagere (Drexel University, Philadelphia, Pennsylvania, USA), and current and past members of the Mani Laboratory for their contributions toward this project as well as their critical comments on the review. Special thanks are due to Matthew Redinbo for the figures not previously present in the literature.

\section{References}

About the cover: St. John's wort. J Soc Integr Oncol. 2006; 4:52-55. [PubMed: 16737673]

Back DJ, Orme ML. Pharmacokinetic drug interactions with oral contraceptives. Clin Pharmacokinet. 1990; 18:472-484. [PubMed: 2191822]

Baciewicz AM, Chrisman CR, Finch CK, Self TH. Update on rifampin and rifabutin drug interactions. Am J Med Sci. 2008; 335:126-136. [PubMed: 18277121]

Barry M, Gibbons S, Back D, Mulcahy F. Protease inhibitors in patients with HIV disease. Clinically important pharmacokinetic considerations. Clin Pharmacokinet. 1997; 32:194-209. [PubMed: 9084959]

Bates DW. Drugs and adverse drug reactions: how worried should we be? JAMA. 1998; 279:12161217. [PubMed: 9555764]

Beard K. Adverse reactions as a cause of hospital admission in the aged. Drugs Aging. 1992; 2:356367. [PubMed: 1504448]

Bending MR, Skacel PO. Rifampicin and methadone withdrawal. Lancet. 1977; 1:1211. [PubMed: 68314]

Benoit G, Malewicz M, Perlmann T. Digging deep into the pockets of orphan nuclear receptors: insights from structural studies. Trends Cell Biol. 2004; 14:369-376. [PubMed: 15246430]

Bertilsson G, Heidrich J, Svensson K, Asman M, Jendeberg L, Sydow-Backman M, et al. Identification of a human nuclear receptor defines a new signaling pathway for CYP3A induction. Proc Natl Acad Sci U S A. 1998; 95:12208-12213. [PubMed: 9770465]

Biswas A, Mani S, Redinbo MR, Krasowski MD, Li H, Ekins S. Elucidating the 'Jekyll and Hyde' nature of PXR: the case for discovering antagonists or allosteric antagonists. Pharm Res. 2009; 26:1807-1815. [PubMed: 19415465]

Biswas A, Pasquel D, Tyagi RK, Mani S. Acetylation of pregnane X receptor protein determines selective function independent of ligand activation. Biochem Biophys Res Commun. 2011; 406:371-376. [PubMed: 21329659]

Blumberg B, Sabbagh W Jr, Juguilon H, Bolado J Jr, van Meter CM, Ong ES, et al. SXR, a novel steroid and xenobiotic-sensing nuclear receptor. Genes Dev. 1998; 12:3195-3205. [PubMed: 9784494]

Borrelli F, Izzo AA. Herb-drug interactions with St John's wort (Hypericum perforatum): an update on clinical observations. AAPS J. 2009; 11:710-727. [PubMed: 19859815]

Burk RF, Hill KE, Hunt RW Jr, Martin AE. Isoniazid potentiation of acetaminophen hepatotoxicity in the rat and 4-methylpyrazole inhibition of it. Res Commun Chem Pathol Pharmacol. 1990; 69:115-118. [PubMed: 2218067]

Buzon V, Carbo LR, Estruch SB, Fletterick RJ, Estebanez-Perpina E. A conserved surface on the ligand binding domain of nuclear receptors for allosteric control. Mol Cell Endocrinol. 2012; 348:394-402. [PubMed: 21878368]

Carnahan VE, Redinbo MR. Structure and function of the human nuclear xenobiotic receptor PXR. Curr Drug Metab. 2005; 6:357-367. [PubMed: 16101574]

Chawla A, Repa JJ, Evans RM, Mangelsdorf DJ. Nuclear receptors and lipid physiology: opening the X-files. Science. 2001; 294:1866-1870. [PubMed: 11729302]

Chen T. Overcoming drug resistance by regulating nuclear receptors. Adv Drug Deliv Rev. 2010; 62:1257-1264. [PubMed: 20691230]

Chen Y, Nie D. Pregnane X receptor and its potential role in drug resistance in cancer treatment. Recent Pat Anticancer Drug Discov. 2009; 4:19-27. [PubMed: 19149685] 
Chen Y, Tang Y, Guo C, Wang J, Boral D, Nie D. Nuclear receptors in the multidrug resistance through the regulation of drug-metabolizing enzymes and drug transporters. Biochem Pharmacol. 2012; 83:1112-1126. [PubMed: 22326308]

Chen Y, Tang Y, Robbins GT, Nie D. Camptothecin attenuates cytochrome P450 3A4 induction by blocking the activation of human pregnane X receptor. J Pharmacol Exp Ther. 2010; 334:999_ 1008. [PubMed: 20504912]

Cheng J, Krausz KW, Tanaka N, Gonzalez FJ. Chronic exposure to rifaximin causes hepatic steatosis in pregnane $x$ receptor-humanized mice. Toxicol Sci. 2012a; 129:456-468. [PubMed: 22790967]

Cheng J, Ma X, Krausz KW, Idle JR, Gonzalez FJ. Rifampicin-activated human pregnane X receptor and CYP3A4 induction enhance acetaminophen-induced toxicity. Drug Metab Dispos. 2009; 37:1611-1621. [PubMed: 19460945]

Cheng J, Shah YM, Gonzalez FJ. Pregnane X receptor as a target for treatment of inflammatory bowel disorders. Trends Pharmacol Sci. 2012b; 33:323-330. [PubMed: 22609277]

Cheng J, Shah YM, Ma X, Pang X, Tanaka T, Kodama T, et al. Therapeutic role of rifaximin in inflammatory bowel disease: clinical implication of human pregnane $\mathrm{X}$ receptor activation. $\mathrm{J}$ Pharmacol Exp Ther. 2010; 335:32-41. [PubMed: 20627999]

Choi JH, Banks AS, Estall JL, Kajimura S, Bostrom P, Laznik D, et al. Anti-diabetic drugs inhibit obesity-linked phosphorylation of PPARgamma by Cdk5. Nature. 2010; 466:451-456. [PubMed: 20651683]

Choi JH, Banks AS, Kamenecka TM, Busby SA, Chalmers MJ, Kumar N, et al. Antidiabetic actions of a non-agonist PPARgamma ligand blocking Cdk5-mediated phosphorylation. Nature. 2011; 477:477-481. [PubMed: 21892191]

Crippin JS. Acetaminophen hepatotoxicity: potentiation by isoniazid. Am J Gastroenterol. 1993; 88:590-592. [PubMed: 8470644]

Curran A, Ribera E. HIV and TB coinfection: using adjusted doses of lopinavir/ritonavir with rifampin. Expert Rev Anti Infect Ther. 2011; 9:1115-1118. [PubMed: 22114961]

Das BC, Madhukumar AV, Anguiano J, Kim S, Sinz M, Zvyaga TA, et al. Synthesis of novel ketoconazole derivatives as inhibitors of the human pregnane $\mathrm{X}$ receptor (PXR; NR1I2; also termed SXR, PAR). Bioorg Med Chem Lett. 2008; 18:3974-3977. [PubMed: 18583127]

de Haan W, de Vries-van der Weij J, Mol IM, Hoekstra M, Romijn JA, Jukema JW, et al. PXR agonism decreases plasma HDL levels in ApoE3-Leiden.CETP mice. Biochim Biophys Acta. 2009; 1791:191-197. [PubMed: 19150509]

di Masi A, De Marinis E, Ascenzi P, Marino M. Nuclear receptors CAR and PXR: Molecular, functional, and biomedical aspects. Mol Aspects Med. 2009; 30:297-343. [PubMed: 19427329]

Dong H, Lin W, Wu J, Chen T. Flavonoids activate pregnane x receptor-mediated CYP3A4 gene expression by inhibiting cyclin-dependent kinases in HepG2 liver carcinoma cells. BMC Biochem. 2010; 11:23. [PubMed: 20553580]

Dou W, Mukherjee S, Li H, Venkatesh M, Wang H, Kortagere S, et al. Alleviation of gut inflammation by Cdx2/Pxr pathway in a mouse model of chemical colitis. PLoS One. 2012; 7:e36075. [PubMed: 22815676]

Dowell JA, Knebel W, Ludden T, Stogniew M, Krause D, Henkel T. Population pharmacokinetic analysis of anidulafungin, an echinocandin antifungal. J Clin Pharmacol. 2004; 44:590-598. [PubMed: 15145966]

Duret C, Daujat-Chavanieu M, Pascussi JM, Pichard-Garcia L, Balaguer P, Fabre JM, et al. Ketoconazole and miconazole are antagonists of the human glucocorticoid receptor: consequences on the expression and function of the constitutive androstane receptor and the pregnane $\mathrm{X}$ receptor. Mol Pharmacol. 2006; 70:329-339. [PubMed: 16608920]

Dvorak Z. Drug-drug interactions by azole antifungals: beyond a dogma of CYP3A4 enzyme activity inhibition. Toxicol Lett. 2011; 202:129-132. [PubMed: 21333771]

Ekins S, Chang C, Mani S, Krasowski MD, Reschly EJ, Iyer M, et al. Human pregnane X receptor antagonists and agonists define molecular requirements for different binding sites. Mol Pharmacol. 2007; 72:592-603. [PubMed: 17576789] 
Ekins S, Kholodovych V, Ai N, Sinz M, Gal J, Gera L, et al. Computational discovery of novel low micromolar human pregnane X receptor antagonists. Mol Pharmacol. 2008; 74:662-672. [PubMed: 18579710]

Fromm MF, Eckhardt K, Li S, Schanzle G, Hofmann U, Mikus G, et al. Loss of analgesic effect of morphine due to coadministration of rifampin. Pain. 1997; 72:261-267. [PubMed: 9272811]

Fuchs I, Hafner-Blumenstiel V, Markert C, Burhenne J, Weiss J, Haefeli WE, et al. Effect of the CYP3A inhibitor ketoconazole on the PXR-mediated induction of CYP3A activity. Eur J Clin Pharmacol. 2012 Sep 12. [Epub ahead of print].

Gollamudi R, Gupta D, Goel S, Mani S. Novel orphan nuclear receptors-coregulator interactions controlling anti-cancer drug metabolism. Curr Drug Metab. 2008; 9:611-613. [PubMed: 18781912]

Goodwin B, Redinbo MR, Kliewer SA. Regulation of cyp3a gene transcription by the pregnane $\mathrm{x}$ receptor. Annu Rev Pharmacol Toxicol. 2002; 42:1-23. [PubMed: 11807162]

Gronemeyer H, Gustafsson JA, Laudet V. Principles for modulation of the nuclear receptor superfamily. Nat Rev Drug Discov. 2004; 3:950-964. [PubMed: 15520817]

Grub S, Bryson H, Goggin T, Ludin E, Jorga K. The interaction of saquinavir (soft gelatin capsule) with ketoconazole, erythromycin, and rifampicin: comparison of the effect in healthy volunteers and in HIV-infected patients. Eur J Clin Pharmacol. 2001; 57:115-121. [PubMed: 11417442]

Guengerich FP. Role of cytochrome P450 enzymes in drug-drug interactions. Adv Pharmacol. 1997; 43:7-35. [PubMed: 9342171]

Guo GL, Moffit JS, Nicol CJ, Ward JM, Aleksunes LA, Slitt AL, et al. Enhanced acetaminophen toxicity by activation of the pregnane X receptor. Toxicol Sci. 2004; 82:374-380. [PubMed: 15456926]

Gupta D, Venkatesh M, Wang H, Kim S, Sinz M, Goldberg GL, et al. Expanding the roles for pregnane $\mathrm{X}$ receptor in cancer: proliferation and drug resistance in ovarian cancer. Clin Cancer Res. 2008; 14:5332-5340. [PubMed: 18765524]

He J, Nishida S, Xu M, Makishima M, Xie W. PXR prevents cholesterol gallstone disease by regulating biosynthesis and transport of bile salts. Gastroenterology. 2011; 140:2095-2106. [PubMed: 21354151]

Healan-Greenberg C, Waring JF, Kempf DJ, Blomme EA, Tirona RG, Kim RB. A human immunodeficiency virus protease inhibitor is a novel functional inhibitor of human pregnane $\mathrm{X}$ receptor. Drug Metab Dispos. 2008; 36:500-507. [PubMed: 18096673]

Hernandez JP, Mota LC, Baldwin WS. Activation of CAR and PXR by dietary, environmental, and occupational chemicals alters drug metabolism, intermediary metabolism, and cell proliferation. Curr Pharmacogenomics Person Med. 2009; 7:81-105. [PubMed: 20871735]

Hoekstra M, Lammers B, Out R, Li Z, Van Eck M, Van Berkel TJ. Activation of the nuclear receptor PXR decreases plasma LDL-cholesterol levels and induces hepatic steatosis in LDL receptor knockout mice. Mol Pharm. 2009; 6:182-189. [PubMed: 19183106]

Holmes VF. Rifampin-induced methadone withdrawal in AIDS. J Clin Psychopharmacol. 1990; 10:443-444. [PubMed: 2286719]

$\mathrm{Hu}$ G, Xu C, Staudinger JL. Pregnane X receptor is SUMOylated to repress the inflammatory response. J Pharmacol Exp Ther. 2010; 335:342-350. [PubMed: 20719936]

Hu ZP, Yang XX, Chen X, Cao J, Chan E, Duan W, et al. A mechanistic study on altered pharmacokinetics of irinotecan by St. John's wort. Curr Drug Metab. 2007; 8:157-171. [PubMed: 17305494]

Huang H, Wang H, Sinz M, Zoeckler M, Staudinger J, Redinbo MR, et al. Inhibition of drug metabolism by blocking the activation of nuclear receptors by ketoconazole. Oncogene. 2007; 26:258-268. [PubMed: 16819505]

Jayasagar G, Krishna Kumar M, Chandrasekhar K, Madhusudan Rao Y. Influence of rifampicin pretreatment on the pharmacokinetics of celecoxib in healthy male volunteers. Drug Metabol Drug Interact. 2003; 19:287-295. [PubMed: 14768975]

Jonker JW, Liddle C, Downes M. FXR and PXR: potential therapeutic targets in cholestasis. J Steroid Biochem Mol Biol. 2012; 130:147-158. [PubMed: 21801835] 
Kakuda TN, Scholler-Gyure M, Hoetelmans RM. Pharmacokinetic interactions between etravirine and non-antiretroviral drugs. Clin Pharmacokinet. 2011; 50:25-39. [PubMed: 21142266]

Kharasch ED, Whittington D, Hoffer C, Krudys K, Craig K, Vicini P, et al. Paradoxical role of cytochrome P450 3A in the bioactivation and clinical effects of levo-alpha-acetylmethadol: importance of clinical investigations to validate in vitro drug metabolism studies. Clin Pharmacokinet. 2005; 44:731-751. [PubMed: 15966756]

Kliewer SA. The nuclear pregnane X receptor regulates xenobiotic detoxification. J Nutr. 2003; 133(Suppl 7):2444S-2447S. [PubMed: 12840222]

Kliewer SA, Goodwin B, Willson TM. The nuclear pregnane X receptor: a key regulator of xenobiotic metabolism. Endocr Rev. 2002; 23:687-702. [PubMed: 12372848]

Kliewer SA, Lehmann JM, Milburn MV, Willson TM. The PPARs and PXRs: nuclear xenobiotic receptors that define novel hormone signaling pathways. Recent Prog Horm Res. 1999; 54:345367. discussion, 67-68. [PubMed: 10548883]

Kliewer SA, Moore JT, Wade L, Staudinger JL, Watson MA, Jones SA, et al. An orphan nuclear receptor activated by pregnanes defines a novel steroid signaling pathway. Cell. 1998; 92:73-82. [PubMed: 9489701]

Kojima H, Sata F, Takeuchi S, Sueyoshi T, Nagai T. Comparative study of human and mouse pregnane $\mathrm{X}$ receptor agonistic activity in 200 pesticides using in vitro reporter gene assays. Toxicology. 2011; 280:77-87. [PubMed: 21115097]

Krausova L, Stejskalova L, Wang H, Vrzal R, Dvorak Z, Mani S, et al. Metformin suppresses pregnane $\mathrm{X}$ receptor (PXR)-regulated transactivation of CYP3A4 gene. Biochem Pharmacol. 2011; 82:1771-1180. [PubMed: 21920351]

Kredo T, Mauff K, Van der Walt JS, Wiesner L, Maartens G, Cohen K, et al. Interaction between artemether-lumefantrine and nevirapine-based antiretroviral therapy in HIV-1-infected patients. Antimicrob Agents Chemother. 2011; 55:5616-5623. [PubMed: 21947399]

Kreek MJ, Garfield JW, Gutjahr CL, Giusti LM. Rifampin-induced methadone withdrawal. N Engl J Med. 1976; 294:1104-1106. [PubMed: 1256526]

Lau AJ, Yang G, Rajaraman G, Baucom CC, Chang TK. Human pregnane X receptor agonism by Ginkgo biloba extract: assessment of the role of individual ginkgolides. J Pharmacol Exp Ther. 2010; 335:771-780. [PubMed: 20739453]

Lazarou J, Pomeranz BH, Corey PN. Incidence of adverse drug reactions in hospitalized patients: a meta-analysis of prospective studies. JAMA. 1998; 279:1200-1205. [PubMed: 9555760]

Lee WM. Acetaminophen and the U.S. Acute Liver Failure Study Group: lowering the risks of hepatic failure. Hepatology. 2004; 40:6-9. [PubMed: 15239078]

Lehmann JM, McKee DD, Watson MA, Willson TM, Moore JT, Kliewer SA. The human orphan nuclear receptor PXR is activated by compounds that regulate CYP3A4 gene expression and cause drug interactions. J Clin Invest. 1998; 102:1016-1023. [PubMed: 9727070]

Lim YP, Ma CY, Liu CL, Lin YH, Hu ML, Chen JJ, et al. Sesamin: a naturally occurring lignan inhibits CYP3A4 by antagonizing the pregnane $\mathrm{X}$ receptor activation. Evid Based Complement Alternat Med. 2012; 2012:242810. [PubMed: 22645625]

Liu CL, Lim YP, Hu ML. Fucoxanthin attenuates rifampin-induced cytochrome P450 3A4 (CYP3A4) and multiple drug resistance 1 (MDR1) gene expression through pregnane $\mathrm{X}$ receptor (PXR)mediated pathways in human hepatoma HepG2 and colon adenocarcinoma LS174T cells. Mar Drugs. 2012; 10:242-257. [PubMed: 22363234]

Lotsch J, Skarke C, Tegeder I, Geisslinger G. Drug interactions with patient-controlled analgesia. Clin Pharmacokinet. 2002; 41:31-57. [PubMed: 11825096]

Mangelsdorf DJ, Thummel C, Beato M, Herrlich P, Schutz G, Umesono K, et al. The nuclear receptor superfamily: the second decade. Cell. 1995; 83:835-839. [PubMed: 8521507]

Mani S, Huang H, Sundarababu S, Liu W, Kalpana G, Smith AB, et al. Activation of the steroid and xenobiotic receptor (human pregnane $\mathrm{X}$ receptor) by nontaxane microtubule-stabilizing agents. Clin Cancer Res. 2005; 11:6359-6369. [PubMed: 16144941]

Masson D, Lagrost L, Athias A, Gambert P, Brimer-Cline C, Lan L, et al. Expression of the pregnane $\mathrm{X}$ receptor in mice antagonizes the cholic acid-mediated changes in plasma lipoprotein profile. Arterioscler Thromb Vasc Biol. 2005; 25:2164-2169. [PubMed: 16123326] 
Meyer UA. Drug interactions. [Article in German]. Schweiz Med Wochenschr. 1976; 106:424-426. [PubMed: 1265457]

Moore JT, Kliewer SA. Use of the nuclear receptor PXR to predict drug interactions. Toxicology. 2000; 153:1-10. [PubMed: 11090943]

Moore LB, Maglich JM, McKee DD, Wisely B, Willson TM, Kliewer SA, et al. Pregnane X receptor (PXR), constitutive androstane receptor (CAR), and benzoate $\mathrm{X}$ receptor (BXR) define three pharmacologically distinct classes of nuclear receptors. Mol Endocrinol. 2002; 16:977-986. [PubMed: 11981033]

Moore TW, Mayne CG, Katzenellenbogen JA. Minireview: Not picking pockets: nuclear receptor alternate-site modulators (NRAMs). Mol Endocrinol. 2010; 24:683-695. [PubMed: 19933380]

Moreau A, Teruel C, Beylot M, Albalea V, Tamasi V, Umbdenstock T, et al. A novel pregnane X receptor and S14-mediated lipogenic pathway in human hepatocyte. Hepatology. 2009; 49:20682079. [PubMed: 19437491]

Moya M, Gomez-Lechon MJ, Castell JV, Jover R. Enhanced steatosis by nuclear receptor ligands: a study in cultured human hepatocytes and hepatoma cells with a characterized nuclear receptor expression profile. Chem Biol Interact. 2010; 184:376-387. [PubMed: 20079722]

Niemi M, Backman JT, Fromm MF, Neuvonen PJ, Kivisto KT. Pharmacokinetic interactions with rifampicin: clinical relevance. Clin Pharmacokinet. 2003; 42:819-850. [PubMed: 12882588]

Novotna A, Doricakova A, Vrzal R, Maurel P, Pavek P, Dvorak Z. Investigation of Orlistat effects on PXR activation and CYP3A4 expression in primary human hepatocytes and human intestinal LS174T cells. Eur J Pharm Sci. 2010; 41:276-280. [PubMed: 20599501]

Orans J, Teotico DG, Redinbo MR. The nuclear xenobiotic receptor pregnane X receptor: recent insights and new challenges. Mol Endocrinol. 2005; 19:2891-2900. [PubMed: 15961506]

Pagliaro L, Felding J, Audouze K, Nielsen SJ, Terry RB, Krog-Jensen C, et al. Emerging classes of protein-protein interaction inhibitors and new tools for their development. Curr Opin Chem Biol. 2004; 8:442-449. [PubMed: 15288255]

Pea F, Pavan F, Furlanut M. Clinical relevance of pharmacokinetics and pharmacodynamics in cardiac critical care patients. Clin Pharmacokinet. 2008; 47:449-462. [PubMed: 18563954]

Poirier A, Funk C, Lave T, Noe J. New strategies to address drug-drug interactions involving OATPs. Curr Opin Drug Discov Devel. 2007; 10:74-83.

Pondugula SR, Mani S. Pregnane xenobiotic receptor in cancer pathogenesis and therapeutic response. Cancer Lett. 2012; 328:1-9. [PubMed: 22939994]

Poulton EJ, Levy L, Lampe JW, Shen DD, Tracy J, Shuhart MC, Thummel KE, Eaton DL. Sulforaphane is not an effective antagonist of the human pregnane X-receptor in vivo. Toxicol Appl Pharmacol. 2012 pii: S0041-008X(12)00471-1.

Raynal C, Pascussi JM, Leguelinel G, Breuker C, Kantar J, Lallemant B, et al. Pregnane X receptor (PXR) expression in colorectal cancer cells restricts irinotecan chemosensitivity through enhanced SN-38 glucuronidation. Mol Cancer 2010. 2010; 9:46.

Reschly EJ, Krasowski MD. Evolution and function of the NR1I nuclear hormone receptor subfamily (VDR, PXR, and CAR) with respect to metabolism of xenobiotics and endogenous compounds. Curr Drug Metab. 2006; 7:349-365. [PubMed: 16724925]

Rosskopf D, Kroemer HK, Siegmund W. Pharmacokinetic problems in clinical practice: role of drug transporters. [Article in German]. Dtsch Med Wochenschr. 2009; 134:345-356. quiz, 57-60. [PubMed: 19206053]

Ruschitzka F, Meier PJ, Turina M, Lüscher TF, Noll G. Acute heart transplant rejection due to Saint John's wort. Lancet. 2000; 355:548-549. [PubMed: 10683008]

Schafer-Korting M. Pharmacokinetic optimisation of oral antifungal therapy. Clin Pharmacokinet. 1993; 25:329-341. [PubMed: 8261715]

Scheen AJ. Pharmacokinetic interactions with thiazolidinediones. Clin Pharmacokinet. 2007; 46:1-12. [PubMed: 17201456]

Shukla SJ, Sakamuru S, Huang R, Moeller TA, Shinn P, Vanleer D, et al. Identification of clinically used drugs that activate pregnane X receptors. Drug Metab Dispos. 2011; 39:151-159. [PubMed: 20966043] 
Staudinger JL, Xu C, Biswas A, Mani S. Post-translational modification of pregnane x receptor. Pharmacol Res. 2011; 64:4-10. [PubMed: 21397695]

Sugatani J, Uchida T, Kurosawa M, Yamaguchi M, Yamazaki Y, Ikari A, et al. Regulation of pregnane $\mathrm{X}$ receptor (PXR) function and UGT1A1 gene expression by posttranslational modification of PXR protein. Drug Metab Dispos. 2012; 40:2031-2040. [PubMed: 22829544]

Sugatani J, Yamakawa K, Tonda E, Nishitani S, Yoshinari K, Degawa M, et al. The induction of human UDP-glucuronosyltransferase 1A1 mediated through a distal enhancer module by flavonoids and xenobiotics. Biochem Pharmacol. 2004; 67:989-1000. [PubMed: 15104253]

Sui Y, Xu J, Rios-Pilier J, Zhou C. Deficiency of PXR decreases atherosclerosis in apoE-deficient mice. J Lipid Res. 2011; 52:1652-1659. [PubMed: 21685500]

Svecova L, Vrzal R, Burysek L, Anzenbacherova E, Cerveny L, Grim J, et al. Azole antimycotics differentially affect rifampicin-induced pregnane X receptor-mediated CYP3A4 gene expression. Drug Metab Dispos. 2008; 36:339-348. [PubMed: 17998298]

Synold TW, Dussault I, Forman BM. The orphan nuclear receptor SXR coordinately regulates drug metabolism and efflux. Nat Med. 2001; 7:584-590. [PubMed: 11329060]

Takeshita A, Taguchi M, Koibuchi N, Ozawa Y. Putative role of the orphan nuclear receptor SXR (steroid and xenobiotic receptor) in the mechanism of CYP3A4 inhibition by xenobiotics. J Biol Chem. 2002; 277:32453-32458. [PubMed: 12072427]

Thornton JW. Evolution of vertebrate steroid receptors from an ancestral estrogen receptor by ligand exploitation and serial genome expansions. Proc Natl Acad Sci U S A. 2001; 98:5671-5676. [PubMed: 11331759]

Venkatesh M, Wang H, Cayer J, Leroux M, Salvail D, Das B, et al. In vivo and in vitro characterization of a first-in-class novel azole analog that targets pregnane $\mathrm{X}$ receptor activation. Mol Pharmacol. 2011; 80:124-135. [PubMed: 21464197]

Vethe NT, Midtvedt K, Asberg A, Amundsen R, Bergan S. Drug interactions and immunosuppression in organ transplant recipients. [Article in Norwegian]. Tidsskr Nor Laegeforen. 2011; 131:2000 2003. [PubMed: 22016125]

Wang H, Huang H, Li H, Teotico DG, Sinz M, Baker SD, et al. Activated pregnenolone X-receptor is a target for ketoconazole and its analogs. Clin Cancer Res. 2007; 13:2488-2495. [PubMed: 17438109]

Wang H, Li H, Moore LB, Johnson MD, Maglich JM, Goodwin B, et al. The phytoestrogen coumestrol is a naturally occurring. antagonist of the human pregnane $\mathrm{X}$ receptor. Mol Endocrinol. 2008; 22:838-857. [PubMed: 18096694]

Wang H, Venkatesh M, Li H, Goetz R, Mukherjee S, Biswas A, et al. Pregnane X receptor activation induces FGF19-dependent tumor aggressiveness in humans and mice. J Clin Invest. 2011; 121:3220-3232. [PubMed: 21747170]

Watkins RE, Davis-Searles PR, Lambert MH, Redinbo MR. Coactivator binding promotes the specific interaction between ligand and the pregnane X receptor. J Mol Biol. 2003a; 331:815-828. [PubMed: 12909012]

Watkins RE, Maglich JM, Moore LB, Wisely GB, Noble SM, Davis-Searles PR, et al. 2.1 A crystal structure of human PXR in complex with the St. John's wort compound hyperforin. Biochemistry. 2003b; 42:1430-1438. [PubMed: 12578355]

Watkins RE, Noble SM, Redinbo MR. Structural insights into the promiscuity and function of the human pregnane X receptor. Curr Opin Drug Discov Devel. 2002; 5:150-158.

Watkins RE, Wisely GB, Moore LB, Collins JL, Lambert MH, Williams SP, et al. The human nuclear xenobiotic receptor PXR: structural determinants of directed promiscuity. Science. 2001; 292:2329-2333. [PubMed: 11408620]

White DB, Batayneh Z, Bachmann KA. A synergism model for PPARalpha and PXR agonist effects on HDL-cholesterol and apoA1. Front Biosci (Elite Ed). 2010; 2:399-410. [PubMed: 20036888]

Xue Y, Chao E, Zuercher WJ, Willson TM, Collins JL, Redinbo MR. Crystal structure of the PXRT1317 complex provides a scaffold to examine the potential for receptor antagonism. Bioorg Med Chem. 2007; 15:2156-2166. [PubMed: 17215127]

Yu C, Chai X, Yu L, Chen S, Zeng S. Identification of novel pregnane X receptor activators from traditional Chinese medicines. J Ethnopharmacol. 2011; 136:137-143. [PubMed: 21524698] 
Zhang B, Cheng Q, Ou Z, Lee JH, Xu M, Kochhar U, et al. Pregnane X receptor as a therapeutic target to inhibit androgen activity. Endocrinology. 2010; 151:5721-5729. [PubMed: 20962047]

Zhou C, King N, Chen KY, Breslow JL. Activation of PXR induces hypercholesterolemia in wild-type and accelerates atherosclerosis in apoE deficient mice. J Lipid Res. 2009; 50:2004-2013. [PubMed: 19436068]

Zhou C, Poulton EJ, Grun F, Bammler TK, Blumberg B, Thummel KE, et al. The dietary isothiocyanate sulforaphane is an antagonist of the human steroid and xenobiotic nuclear receptor. Mol Pharmacol. 2007; 71:220-229. [PubMed: 17028159]

Zhou J, Febbraio M, Wada T, Zhai Y, Kuruba R, He J, et al. Hepatic fatty acid transporter Cd36 is a common target of LXR, PXR, and PPARgamma in promoting steatosis. Gastroenterology. 2008; 134:556-567. [PubMed: 18242221] 


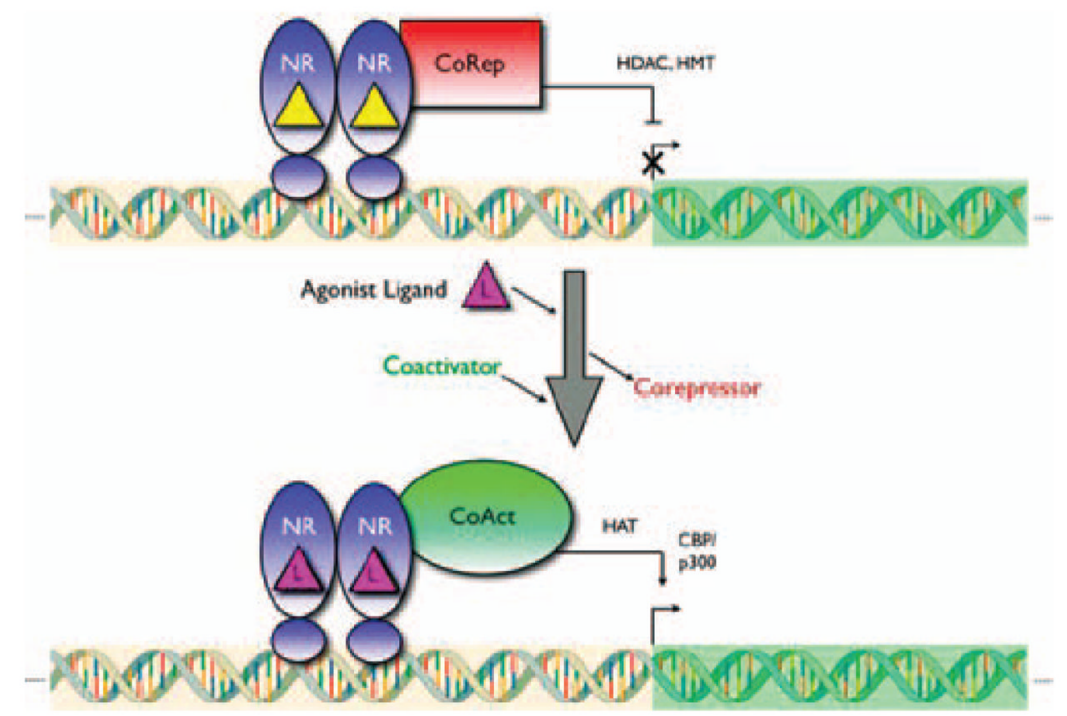

Figure 1.

Transcriptional activation by NRs. 


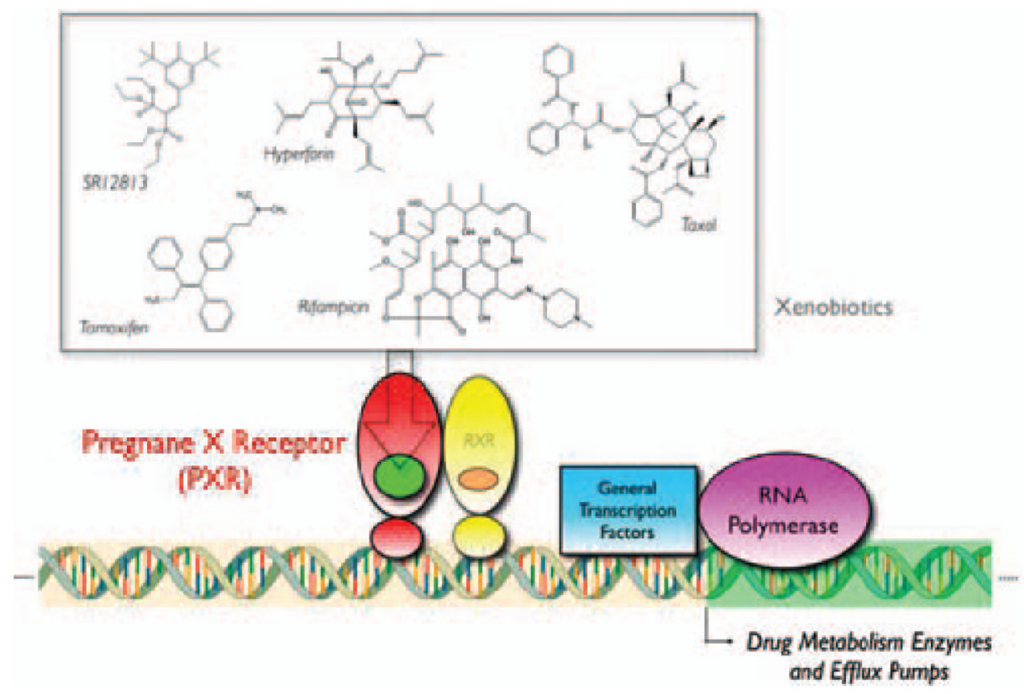

Figure 2.

LBD promiscuity of PXR. 


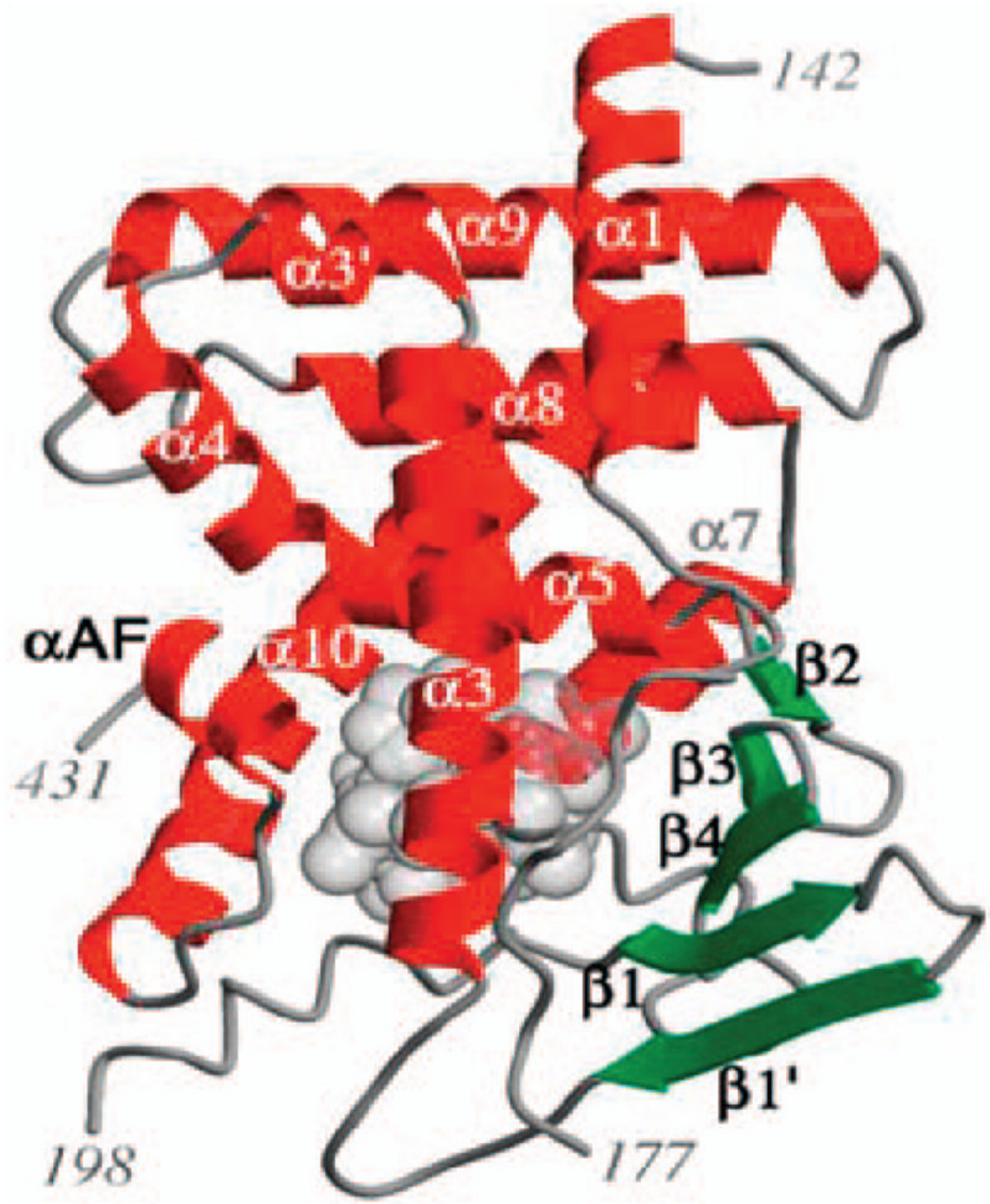

Figure 3.

PXR-LBD scaffold. 

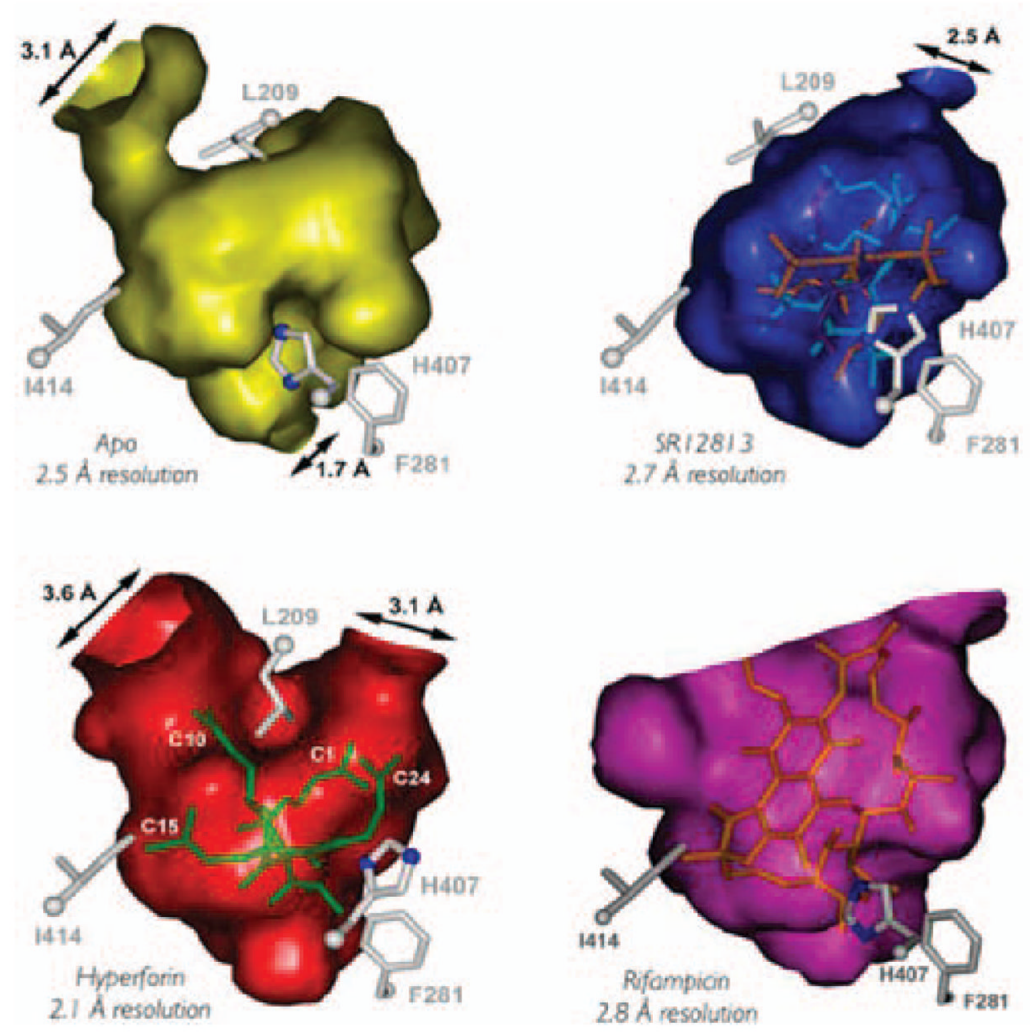

Figure 4.

Ligand binding induces changes in the molecular surface of the PXR-binding pocket. 


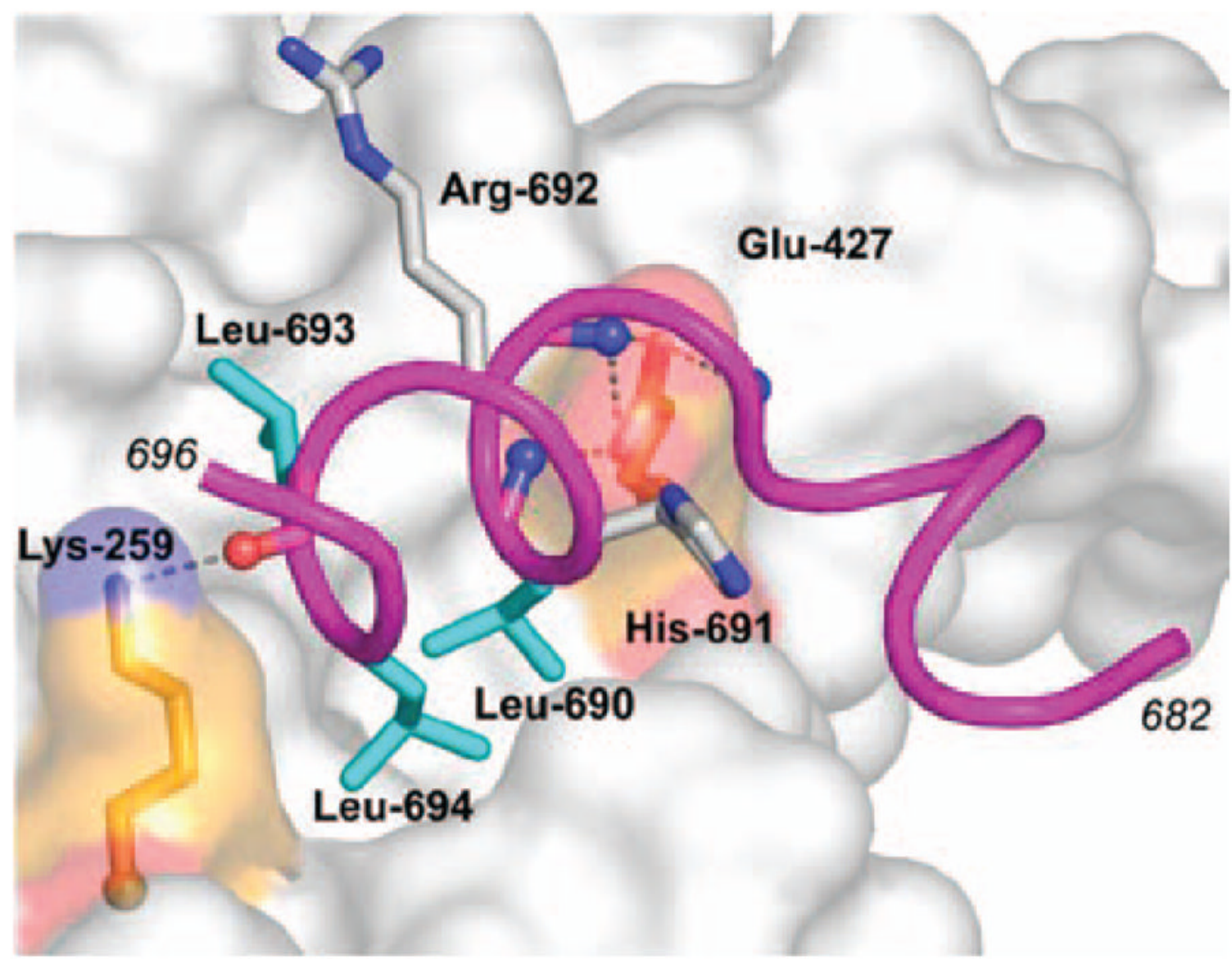

Figure 5.

Fragment of the SRC-1 coactivator (magenta and cyan) bound to the AF-2 site of the human PXR (receptor residues Lys-259 and Glu-427 highlighted). 

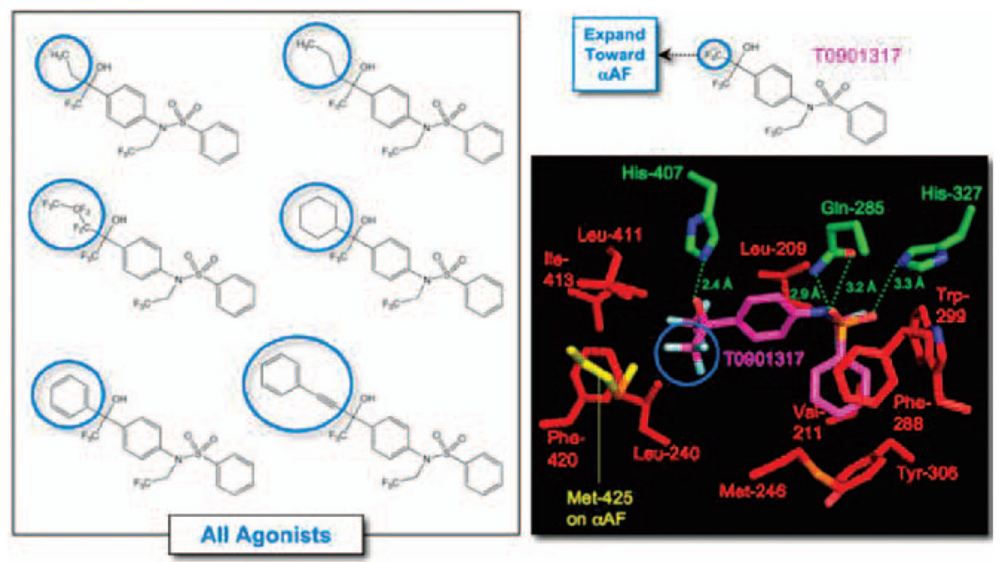

Figure 6.

Several analogs of the high-affinity PXR agonist, T0901317 (T1317; magenta) were synthesized with the aim of disrupting PXR function by sterically blocking a AF position. Large substituent groups were added to the T1317 scaffold (blue); however, analogs still functioned as agonists because of the flexibility of PXR. 

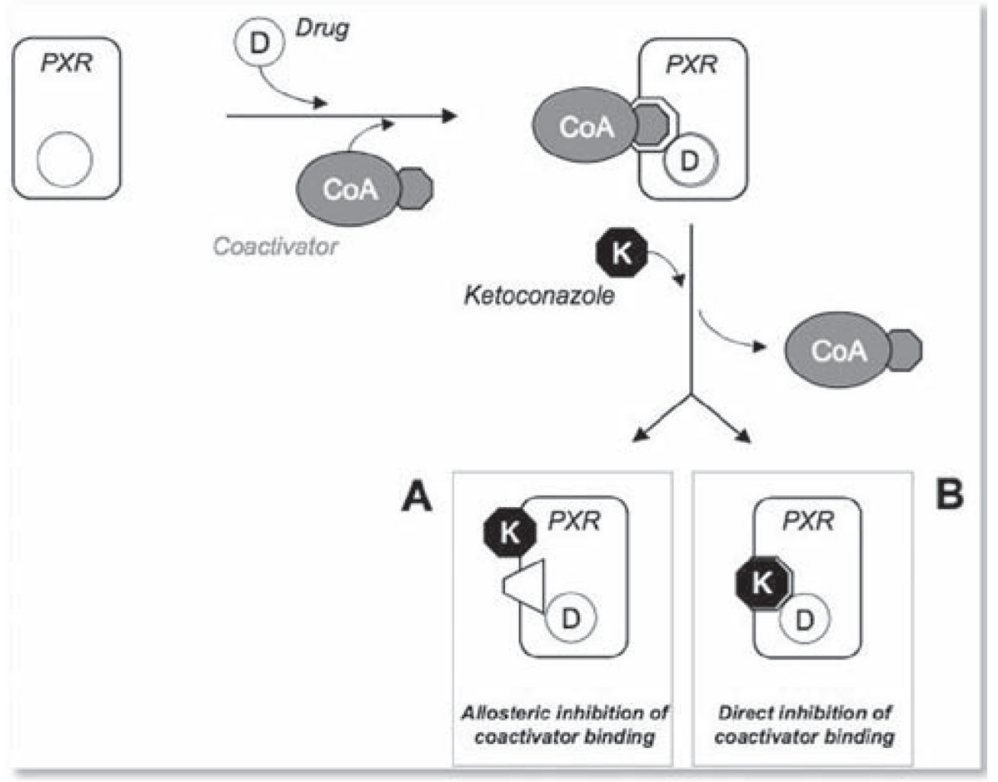

Figure 7.

Proposed mechanism of ketoconazole's antagonism of human PXR. 


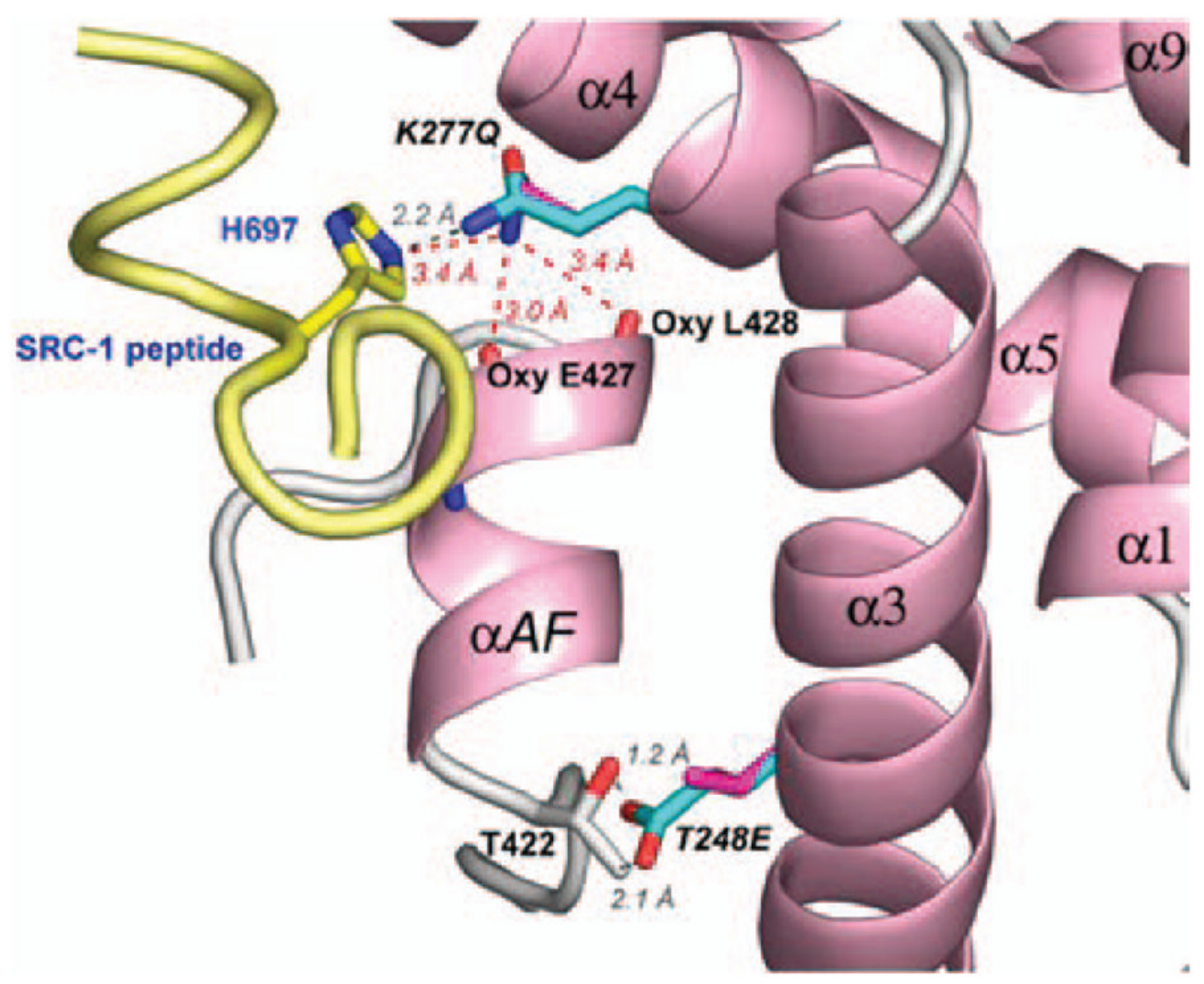

Figure 8.

Form of PXR containing two targeted mutants (K277Q and T248E; cyan) that mimic residues found in steroid receptors insensitive to ketoconazole is not antagonized by this drug. 


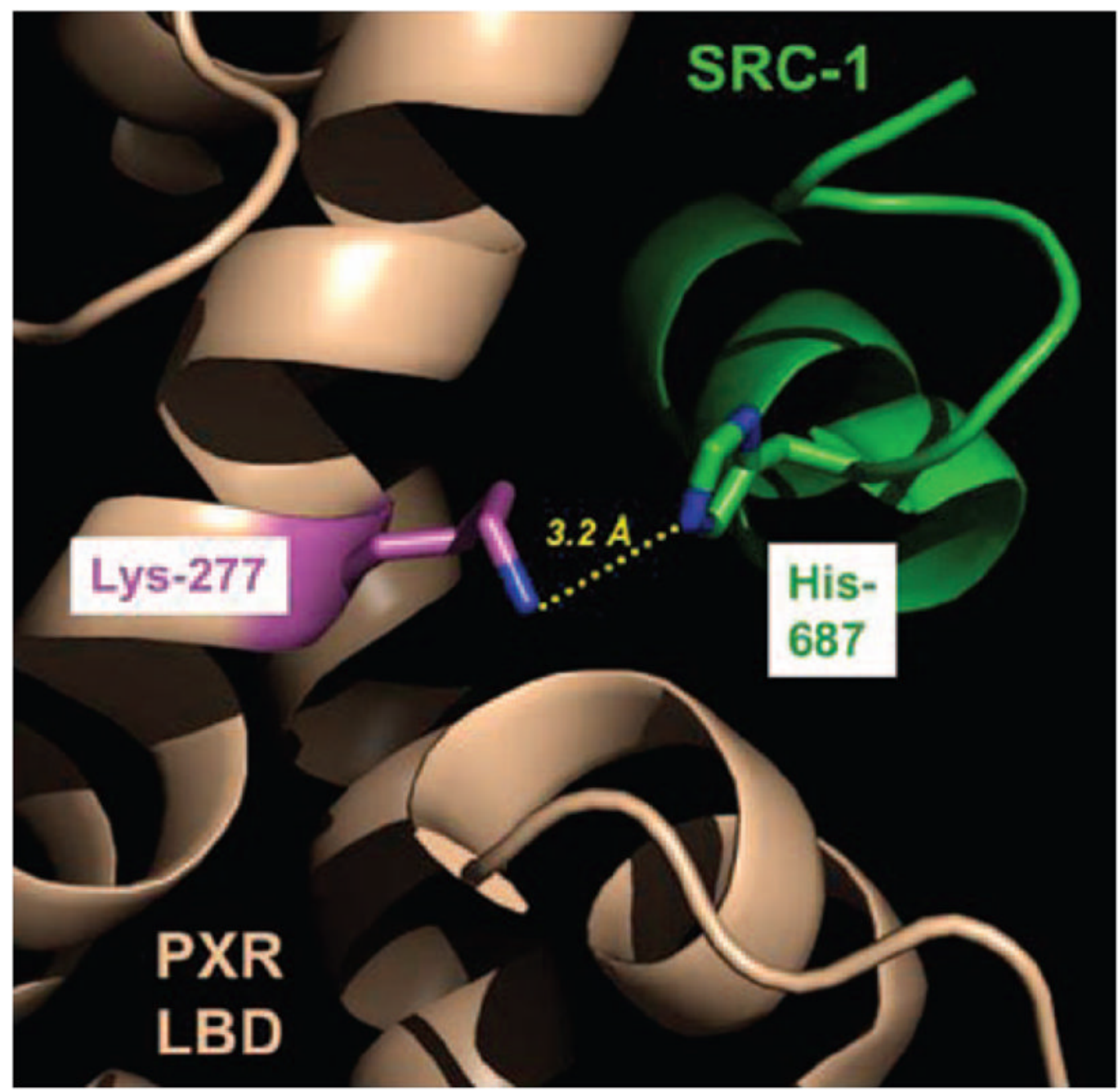

Figure 9.

K277-H687 contact in the PXR-SRC1 complex structure. 

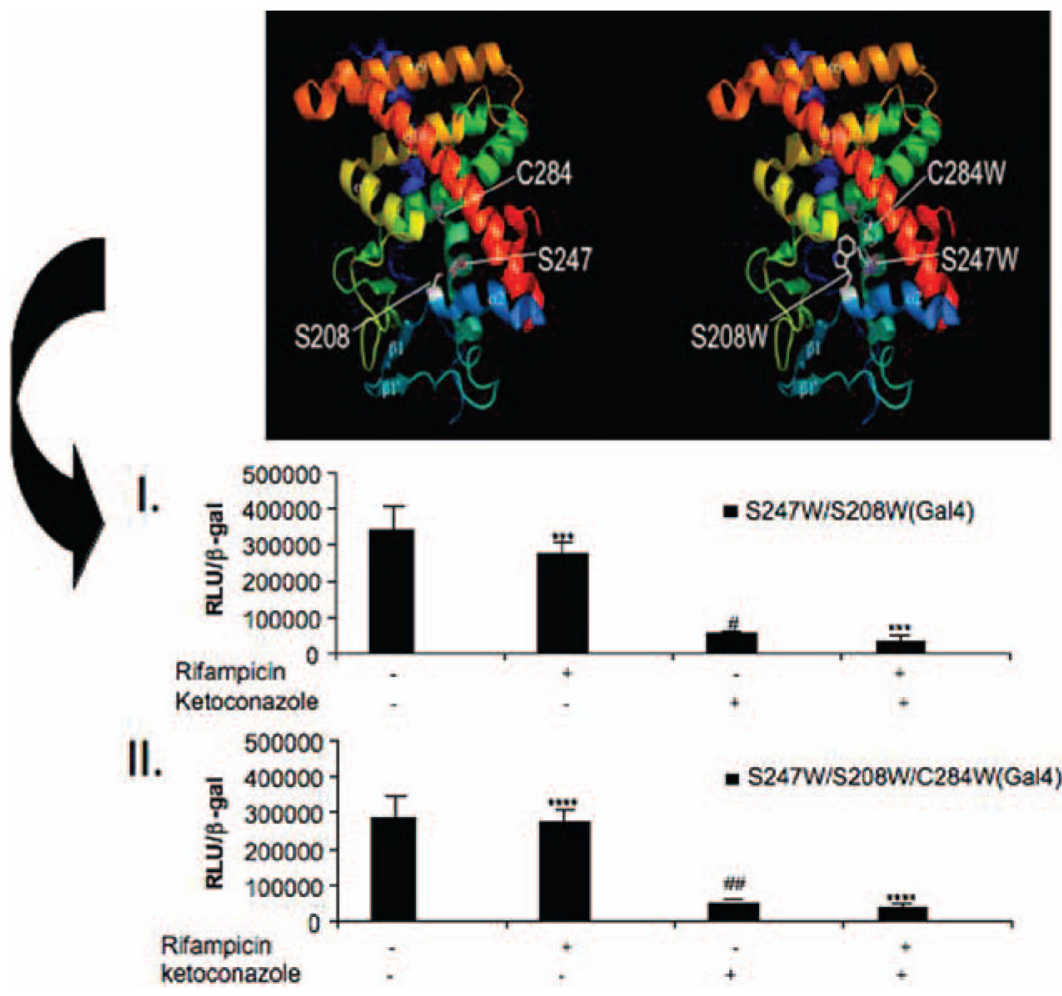

Figure 10.

Left: Designed mutants fill the pocket of PXR. Right: Double (I) and triple (Wang et al., 2008) mutant forms of PXR are insensitive to binding-pocket-targeted agonists, but are still antagonized by ketoconazole. 

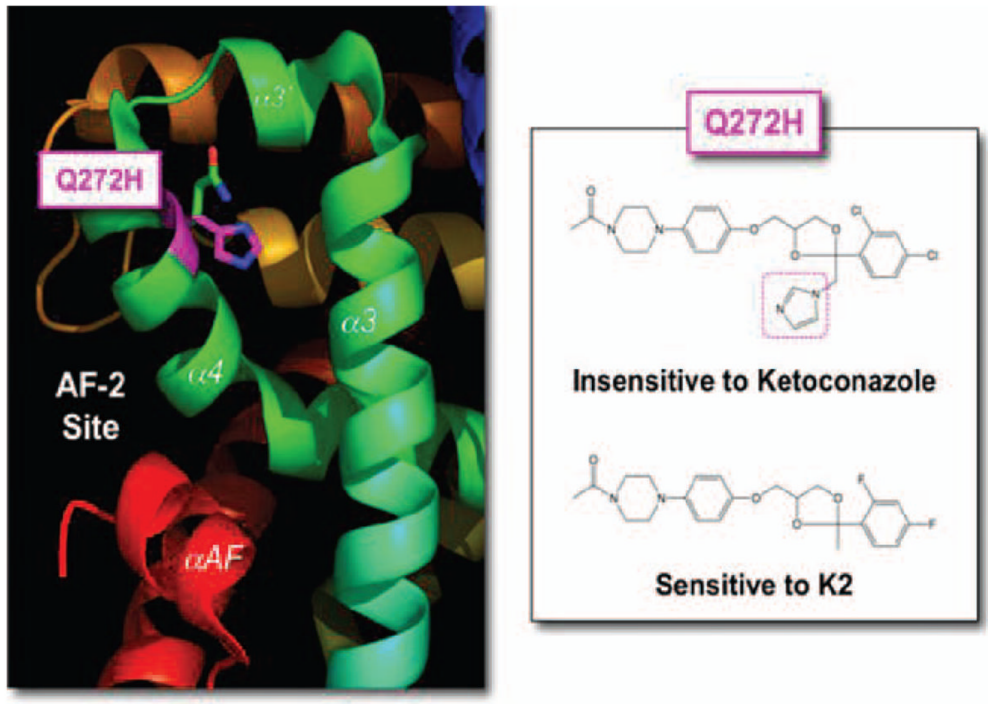

Figure 11.

Q272H mutation, identified by yeast-screening methods, is located at the surface AF-2 site on PXR. This form of PXR is insensitive to ketoconazole, but sensitive to K2 (see Figure 7; also called "compound 3"). 


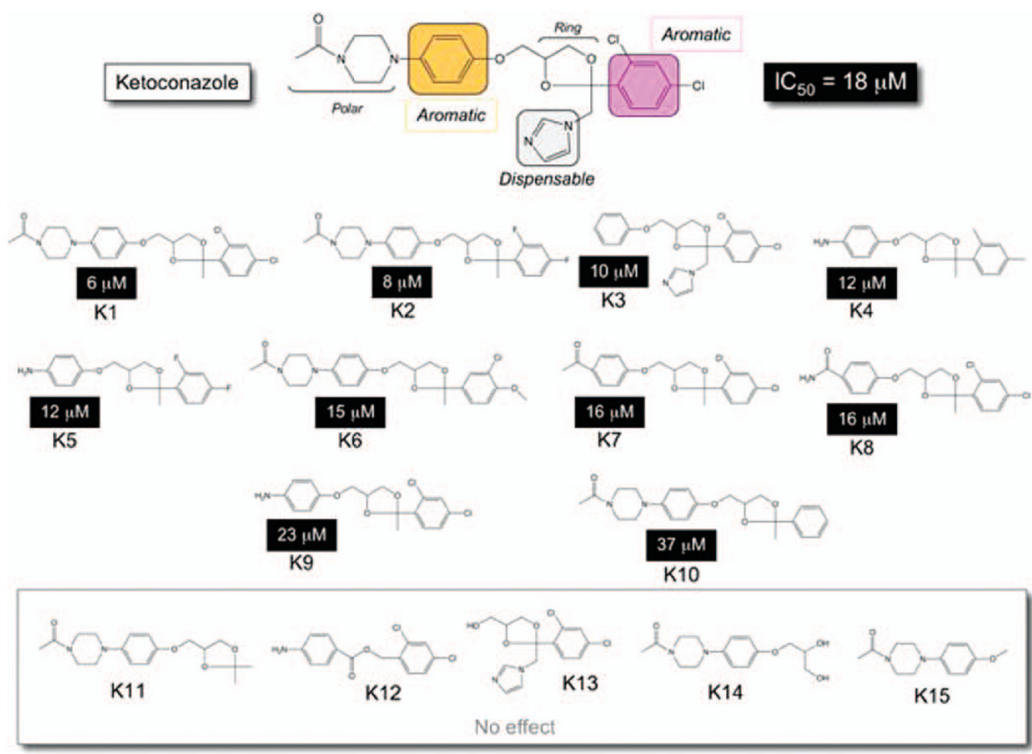

Figure 12.

Fifteen analogs of ketoconazole establish SARs for PXR antagonism. $\mathrm{IC}_{50}$ values were obtained from transient transfections in Fa2N cells (performed four separate times, each in duplicate) and represent the dose-dependent inhibition of PXR-mediated transcription of a reporter gene in the presence of $10 \mu \mathrm{M}$ of rifampicin, an established PXR agonist. 

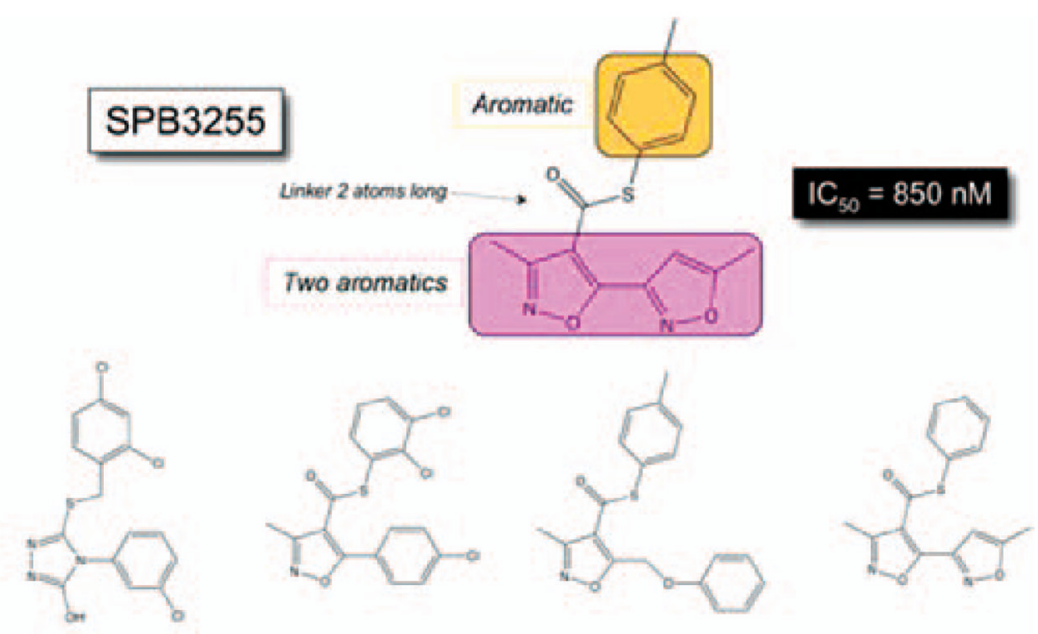

\section{$\mathrm{IC}_{50}=1.5 \mu \mathrm{M}$}

$\mathrm{IC}_{50}=5 \mu \mathrm{M}$

$\mathrm{IC}_{50}=16 \mu \mathrm{M}$

$\mathrm{IC}_{50}=5 \mu \mathrm{M}$

S1

$\mathrm{S} 2$

S3

S4

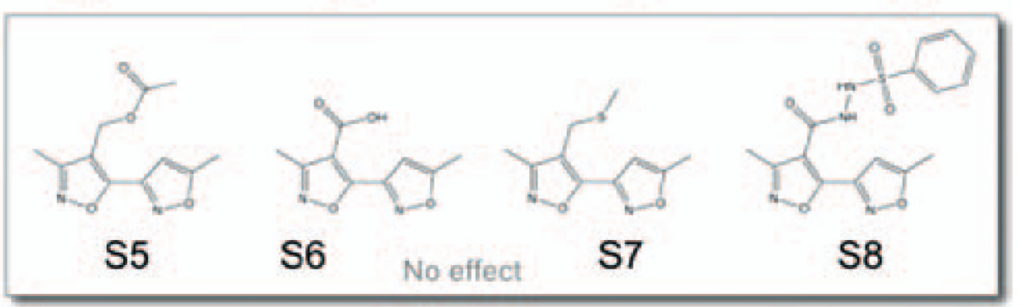

Figure 13.

Eight analogs of SPB3255 establish SARs for PXR antagonism. IC $_{50}$ values were obtained from transient transfections in HepG2 cells and represent the dose-dependent inhibition of PXR-mediated transcription of a reporter gene in the presence of $10 \mu \mathrm{M}$ of rifampicin, an established PXR agonist. 


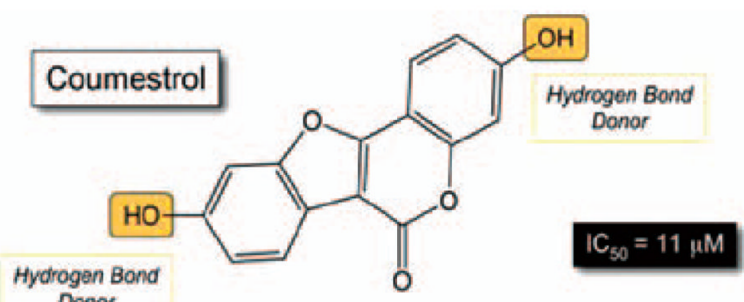
Donor

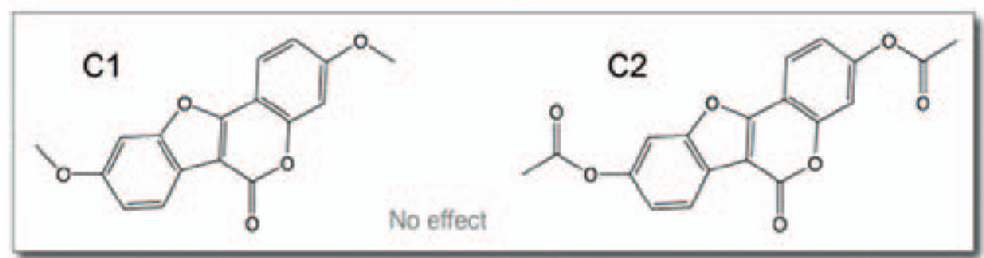

Figure 14.

Hydrogen bond donors are essential for the PXR antagonism activity of coumestrol. 


\section{Table 1}

Example of corresponding amino acids on NRs in the aAF surface that affect aAF stability.

\begin{tabular}{lcc}
\hline NR & aAF amino acid (1) & aAF amino acid (2) \\
\hline PXR & T248 & K277 \\
CAR & T248 & K277 \\
FXR & T248 & K277 \\
LXR & I276 & K277 \\
AR & K709 & H738 \\
ER & E353 & Q375 \\
PR & E723 & W752 \\
\hline
\end{tabular}

